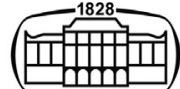

AKADÉMIAI KIADÓ

Hungarica

69 (2021) 4, 315-323

DOI:

$10.1556 / 004.2021 .00045$

(c) 2021 The Author(s)

\title{
Role of genes related to performance and reproduction of Thoroughbreds in training and breeding - A review
}

Acta Veterinaria

\section{JUDIT KIS ${ }^{1}$, LÁSZLÓ RÓZSA ${ }^{1}$, FERENC HUSVÉTH ${ }^{2}$, ATTILA ZSOLNAI $^{1 *}$ ๑ and ISTVÁN ANTON ${ }^{1}$}

\author{
${ }^{1}$ Department of Animal Breeding, Institute of Animal Science, Hungarian University of Agriculture \\ and Life Sciences, Kaposvár Campus, Guba Sándor u. 40, H-7400 Kaposvár, Hungary \\ ${ }^{2}$ Department of Animal Breeding, Institute of Animal Science, Hungarian University of Agriculture \\ and Life Sciences, Georgikon Campus, Hungary
}

Received: 1 June 2021 • Accepted: 1 October 2021

Published online: 2 November 2021

\section{REVIEW ARTICLE}

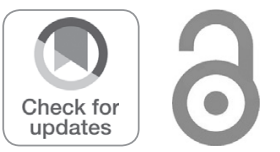

Corresponding author.

E-mail: attila.zsolnai@gmail.com

\begin{abstract}
Thoroughbreds have been selected for speed and stamina since the 1700s. This selection resulted in structural and functional system-wide adaptations that enhanced physiological characteristics for outstanding speed of 61-71 kph (38-44 mph) between 1,000 and 3,200 m (5 furlongs - 2 miles). At present, horseracing is still an economically important industrial sector, therefore intensive research is underway to explore genes that allow the utilisation of genetic abilities and are significant in breeding and training. This study aims to provide an overview of genetic research and its applicability related to Thoroughbreds.
\end{abstract}

\section{KEYWORDS}

Thoroughbreds, genetic markers, competitive performance, candidate gene

\section{INTRODUCTION}

The ability of Thoroughbreds to compete over 5 furlongs is different from those running on 16 furlongs; nevertheless, they could receive the same judgement if the estimation criterion of their performance would be prize money. Winner prize money can offer a confirmation that both categories are able to carry off races of a certain standard, however, this fact does not imply their genomic equivalence (Williamson and Beilharz, 1996).

People have bred many plants and animals throughout history that carried a wide range of desirable and profitable traits (Ross-Ibarra et al., 2007). Investigation of the domestication process provided an excellent opportunity to understand the genetic basis of phenotypic variations, as well as the effect of directed selection on genome evolution, bottleneck effect, and inbreeding (Larson and Burger, 2013). Recent studies investigating ancient genomes have provided many insights into the domestication history of horses (Orlando et al., 2013; Librado et al., 2016, 2017). Competent pieces of evidence show that domestication began about 5,500 years ago, which involved a bottleneck effect and consequently a decrease in genetic diversity (Schubert et al., 2014). Since that time several breeds have been developed showing large phenotypic variation. One of the most popular breeds is the Thoroughbred which originates back to the 18th century. Since that time Thoroughbreds have been selected exclusively for high speed and stamina (Wallner et al., 2013).

Over their 300-year-long breeding history, consequent selection for structural and functional adaptations has resulted in the development of an athletic phenotype (Williamson and Beilharz, 1998; Cunningham et al., 2001). 
Nowadays it is believed that abnormally large heart size (non-disease-induced hypertrophy) can have a positive effect on the competitive performance of Thoroughbreds. Previous pedigree analyses suggested that larger than average heart size and altered electrocardiogram (ECG) in some horses may be a family- or breed-specific trait (Vörös et al., 1991; Buhl et al., 2005), and thus have a genetic component. Genes responsible for cardiac development, cardiac regulation and heart size (MYH7, CASQ2, AKT1, and $\mathrm{PI} 3 \mathrm{~K}$ ) have been identified in humans and laboratory animal species (Kritz et al., 2000). These genes are well conserved in vertebrates and many invertebrate species and have been shown to play a key role in determining heart rate and growth (Hinchcliff et al., 2008).

The strong cardiovascular system and highly vascular pulmonary system of Thoroughbreds allow their bodies to cope with the increased oxygen demand during heavy exercises (Hinchcliff et al., 2008; Gu et al., 2009). The need to provide increased muscle mass and oxygen demand resulted in higher heart mass. Besides heart size differences, Thoroughbreds generally have better heart symmetry than other horse breeds (Buhl et al., 2005).

It is still widely believed in the horse racing industry that some crosses can contribute to a larger heart size, which results in higher oxygen level and outstanding performances (Buhl et al., 2005). Larger-than-average heart size was first discovered in Thoroughbred individuals post mortem. As an alternative to necropsy, non-invasive electrocardiography (ECG) examinations were used later, which provided an opportunity to examine heart function and predict heart size. More recently, other techniques such as Doppler ultrasonography or echocardiography have been used to examine the living organ (Vörös, 1997; Zucca et al., 2008).

It is a well-known fact that it is rather difficult to determine the racing ability of Thoroughbreds and when evaluating it, many parameters must be taken into account. Performance parameters can be ranked based on phenotypic metrics such as handicap number, winning time or prize money; however, these cannot be compared to the unique phenotypic character and value of the animals (Williamson and Beilharz, 1998). Over the last two decades, DNA sequencing was explosively developed and the reference genome also became available. However, genomic information is still not fully exploited in everyday breeding management (Wade et al., 2009). Thoroughbreds are valuable subjects of genomic studies because of their detailed pedigree information which can help characterise different phenotypes (Tozaki et al., 2016). Microsatellite-based selection studies have identified hundreds of domesticated genes in Thoroughbreds, suggesting that myostatin (MSTN) gene is not the only determinant of athletic phenotype and competitive performance (Lee, 2007; Gu et al., 2009).

The horse racing industry requires the breeding of elite racehorses with outstanding abilities which can perform at the highest level on the most famous racecourses in the world. However, racing ability and competitive performance are multifactorial traits that are influenced by several highimpact gene variants. The study of many low-impact genes is also timely. Hereby we would like to provide a comprehensive picture of candidate genes affecting gene expression, signalling pathways and their influence on training and breeding.

\section{REVIEW OF CURRENT KNOWLEDGE ON THE GENES PRESUMABLY HAVING THE GREATEST IMPACT ON THE COMPETITIVE PERFORMANCE OF THOROUGHBREDS}

\section{MSTN (myostatin gene)}

Previous genome-wide association studies (GWAS) have identified genetic markers that are related to the competitive performance of Thoroughbreds. One of these performancerelated genes was myostatin (MSTN), which became the most important molecular marker in Thoroughbred breeding and racing. Myostatin cDNA from a Thoroughbred was isolated and sequenced by Hosoyama et al. (2002). The MSTN gene which contains three exons was mapped to the equine chromosome 18 genomic region (Caetano et al., 1999).

MSTN belongs to the transforming growth factor $\beta$ superfamily that regulates the growth of muscle fibres, thus limiting skeletal muscle mass (McPherron et al., 1997). This gene has a great impact on the best race distance and racing ability (Bower et al., 2012; Todd et al., 2018) through the regulation of skeletal muscle development (Grobet et al., 2003; Binns et al., 2010; Hill et al., 2010).

The novel MSTN polymorphism (g.66493737C>T) that is strongly associated with best race distance was described for the first time by Hill et al. (2010). Association studies demonstrated that the $\mathrm{C} / \mathrm{C}$ genotype is suited to shorter distance racing, $\mathrm{C} / \mathrm{T}$ animals are appropriate for middledistance races, while $\mathrm{T} / \mathrm{T}$ horses are related to longer distances and increased stamina. Besides, $\mathrm{C} / \mathrm{C}$ animals have significantly greater muscle mass than $\mathrm{T} / \mathrm{T}$ Thoroughbreds (Hill et al., 2010). Prediction of the genetic potential and of the athletic phenotype has a major importance in the Thoroughbred horse industry.

\section{PI3K (phosphinososidide-3-kinase regulatory substance 1 gene)}

Insulin stimulates glucose transport through a number of transcriptionally active signalling pathways to maintain glucose homeostasis (O'Brien and Granner, 1996). One of these, the PI3K pathway plays a key role in skeletal muscle insulin-stimulated glucose transport (Hayashi et al., 1998; $\mathrm{Gu}$ et al., 2009) and its interaction with insulin receptor substrate 1 (IRS1) (Andreelli et al., 1999) and phosphoinoside-3-kinase, regulatory subunit 1 (PIK3R1) by regulating gene expression through insulin. In mice, it plays a role in myocardial cell size formation and muscle contraction (Alliouachene et al., 2016). The PI3K family is highly conserved in evolution, regulates many important cellular 
responses, controls cell proliferation, and is also involved in cell size formation (Crackower et al., 2002). The insulin receptor signalling genes are as follow: FOXO1A (transcription factor), GRB2 (growth factor receptor bound protein 2), PTPN1 (protein tyrosine phosphatase 1), SOCS3 (suppressor of cytokine signalling 3), SOCS7 (cytokine signal suppressor 7) and STXBP4 (syntaxin binding protein 4). A 12,219-base-pair-long transcript of the PI3K gene occurs in Equidae, containing 15 exons (each coding).

The PI3K signalling pathway is also important in physiological research because the development of biomarkers related to ovarian function may help to explore fertility problems (Ginther et al., 2004). The anatomical structure of the ovaries in mares is unique (Ono et al., 2015): the ovary is a significantly large and heavy organ with thick connective tissue (McCue, 1998). Activation of primordial follicles in the ovary indicates the beginning of follicular genesis, which requires perfect control to maintain stable function and reproductive potential (Sutherland et al., 2012). PI3K/protein kinase B or Janus kinase/signal transducer and transcriptional activator (JAK/STAT) signalling pathways play a significant role in stimulating primordial follicles (John et al., 2008; Sutherland et al., 2010). Hall et al. (2018) studied these two signalling pathways by measuring the mRNA expression of six genes that play a significant role in follicular development and by the localisation of several important proteins [PI3K, AKT1, phosphatase and tensin homologue (PTEN), JAK1, STAT3 and cytokine 4 signal suppressor (SOCS4)]. Gene expression was compared in fetal tissues and adult mare ovarian tissues. mRNA expression (PI3K, AKT1, PTEN, JAK1, STAT3, and SOCS4) in mare ovarian samples was significantly higher than in fetal ovarian tissues. These results highlighted the fact that, like other previously studied mammalian species, horses also proved to be useful in the development of ovarian biomarkers.

\section{PYGM (glycogen phosphorylase, muscle associated gene)}

The PYGM gene encodes a skeletal muscle type using glycogen phosphorylase (myophosphorylase). This gene has been shown to catalyse the breakdown of glycogen to glucose-1-phosphate in Thoroughbreds (Nam et al., 2011). Thus, the gene can contribute to the body's energy supply by dissolving the glycogen in the muscle tissue. Northern blot analysis detected a single $3.4-\mathrm{kb}$ mRNA in muscle phosphorylase-expressing tissues and demonstrated the presence of this transcript in the skeletal muscle of mammals where it regulates the degradation of glycogen (Gautron et al., 1987). The PYGM enzyme can increase energy level by enabling the release of glycogen in skeletal muscle. This gene has also been associated with McArdle's disease (glycogen storage disease V) caused by various mutations in the coding exons (Bruno et al., 1999; Martin et al., 2001).

McArdle's disease has been studied in both ruminants and humans (Tan et al., 1997): it is manifested in exercise intolerance, muscle pain, dystonia, rhabdomyolysis and transient myoglobinuria (muscle dye urination) (NadajPakleza et al., 2009). Due to the above-mentioned symptoms, patients with McArdle's disease have difficulties in performing tasks related to muscle work and physical exertion. Therefore, it is hypothesised that abnormal expression of the PYGM gene may lead to muscle phosphorylase deficiency and thus directly affects exercise (Bourque, 2009).

\section{TLR (toll-like receptor gene)}

Respiratory diseases, including Inflammatory Airway Disease (IAD), are caused by viral or bacterial pathogens and are a known problem of racehorses. Respiratory diseases constitute the second most common disorder (Traub-Dargatz et al., 1991) which requires veterinary medical care in adult horses and can cause huge economic losses to the Thoroughbred industry (Wilsher et al., 2006). The airway epithelium forms a significant physical barrier to airborne infections and plays an essential role in the innate immune response of lungs, mainly through the activation of toll-like receptors (TLR). The pathophysiology of these respiratory diseases, especially the function of innate and adaptive immune mechanisms, is currently not fully understood. However, intensive training has been reported to alter the innate immune response in the lungs and systemic circulation (Frellstedt et al., 2014).

The lung's innate immune defence against pathogens also includes the airway epithelium, which interacts strongly with other resident cells and leukocytes. In fact, the respiratory epithelium plays a fundamental role in providing a physical barrier between the external environment and the host (Vareille et al., 2011). On the other hand, it regulates the immune response in case of inflammatory reactions and pathogens.

The ciliated/vibratiled airway epithelium prevents the colonisation of inhaled bacteria through their physical removal by cilia, emptying with coughing, the use of antimicrobial proteins in the mucosa and the production of phagocyte cells (Diamond et al., 2000). The various pathogen recognition receptors (PRRs) on the immune cell surface or in the intracellular compartments of immune cells interact with pathogen-associated molecular patterns (PAMPs) and control defence mechanisms of hosts. Tolllike receptors (TLRs) are important markers which recognise the PAM patterns (Akira et al., 2006).

It heterodimerises with TLR2, TLR1, or TLR6 receptors: TLR1/2 and TLR2/6 recognise the molecular pattern characteristic of Gram-positive bacteria. TLR3 mediates the response to double-stranded RNA, which is a marker of viral infection. TLR4 recognises bacterial lipopolysaccharides (LPS) specific for Gram-negative bacteria. TLR5 responds to flagellin, which is found on flagellated bacteria. TLR7/8 recognise viral single-stranded RNA. Finally, TLR9 mediates the response to unmethylated DNA (CpG), which may be a part of bacteria or viruses (Akira et al., 2006). After the stimulation of TLR by PAMP, a downstream cascade is activated, resulting in the production of interferons (IFNs), 
anti-inflammatory cytokines, chemokines, and cytotoxic agents (Gleeson et al., 2006). TLR9 has been studied in humans, mice, and some domesticated species. TLRs are members of a protein family which form a phylogenetically ancient system and are expressed in both vertebrate and invertebrate species. The ligands of these receptors are pathogenic microbes, i.e. PAMPs. Viral and bacterial (ligand) DNA contains unmethylated CpG motifs that are recognised by the mammalian immune system. TLR9 is known as a receptor that filters out these unmethylated CpG motifs. Receptor-mediated signalling inflicts a proinflammatory cytokine response that affects both innate and adaptive immune responses (Griebel et al., 2005).

It has been previously reported that CpG-stimulated equine peripheral blood mononuclear cells induce TLR9 expression and enhance the immune response (Manuja et al., 2014).

\section{HTR1A (serotonin receptor $1 \mathrm{~A}$ gene)}

In the case of racehorses, easy handling, trainability and cooperation of the horse with the rider are very important parameters. Equine behaviour can be influenced by a number of factors, of which anxiety is particularly important because stressed, anxious animals are more likely to panic which ends in a loss of control (Hori et al., 2015).

Serotonin - a neurotransmitter - and its receptors play an important role in the regulation of anxiety and stress in many animal species and also in humans (Lucki, 1998). One subtype of the serotonin receptor, 1A (HTR1A, 5-hydroxytryptamine receptor $1 \mathrm{~A}, \mathrm{G}$ protein-coupled), is particularly important in the regulation of stress levels (Ramboz et al., 1998; Gross et al., 2002). Polymorphisms in the gene encoding HTR1A have been associated with several psychiatric disorders, including anxiety-related disorders (Drago et al., 2008). For example, a single nucleotide polymorphism (SNP) in the promoter region of HTR1A (g.1019C> G) can increase the risk of depression, suicide, and panic disorder in humans (Lemonde et al., 2003). Association between the serotonin receptor gene and aggression has been previously studied in dogs (Van Den Berg et al., 2008; Vage et al., 2010). While an experiment on Golden Retrievers (Van Den Berg et al., 2008) showed no association between serotonin receptor genes (HTR1A, HTR1B, and HTR2A) and aggression, a study on English Cocker Spaniels (Vage et al., 2010) demonstrated that other serotonin receptor genes (HTR1D, HTR2C) have a significant effect on the studied trait. In equine species, two SNPs have been described in the coding region of the HTR1A gene (Momozawa et al., 2007). These SNPs are nonsynonymous substitutions that can modify the amino acid encoded by a protein, thereby also influencing behaviour. Hori et al. (2015) further investigated the two previously described SNPs and demonstrated that one of them (c.709G> A) causes an amino acid change in the intracellular region of the HTR1A receptor gene that also affects equine behaviour. Five main behavioural components were identified in oneyear-old Thoroughbreds. Four of them were affected by this
SNP in mares and one trait in stallions. Horses carrying the A allele (c.709G $>$ A) were found to be less controllable/easy handleable during the experiment. This result was the first evidence that a polymorphism in a serotonin-related gene can affect the temperament of animals, with partially different sex-based effects.

\section{Effect of the P53 gene on reproduction}

The p53 tumour suppressor protein plays an important role in mammalian reproduction through transcriptional regulation of leukaemia inhibitory factor (LIF), a key cytokine in blastocyst implantation ( $\mathrm{Hu}, 2009)$. The SNP in codon 72, exon 4 of the p53 gene, encodes the amino acid proline (Pro) or arginine (Arg) (Buchman et al., 1988). In humans, this SNP has been associated with cancer development (Lin et al., 2008) and reproductive efficiency ( $\mathrm{Hu}, 2009)$. Previous studies have also associated p53 polymorphisms with sequential implant failure of embryos and miscarriage (Coulam et al., 2006; Kay et al., 2006).

Although the genomic sequence of the equine species is already known (Wade et al., 2009), exon 4 of the p53 gene has not yet been fully characterised due to a gap in the genome at this point. There is also limited information available on the effect of p53 gene polymorphisms on horses. The single nucleotide polymorphism of the p53 gene results in three genotypes: Arg/Arg, Arg/Pro, and Pro/Pro.

These genotypes were compared with available breeding data by Leon et al. (2012). For the 105 English Thoroughbred mares included in the study, allele frequency (codon 72 , exon 4) was 73.3\% Arg/Pro, 17.1\% Arg/Arg, and 9.6\% Pro/ Pro. Results showed that the Arg/Pro heterozygous genotype was associated with an increased likelihood of miscarriage, while the homozygous Pro/Pro genotype decreased the risk of fetal loss. There was an association between miscarriage and the presence of Arg, whether found in homozygous or heterozygous form. According to previously recorded breeding information, Arg was found (in homo- or heterozygous form) in 25 (96.2\%) of all 26 foal loss cases.

\section{Effect of LGB1 and LGB2 (genes encoding $\beta$-lactoglobulin) on the milk of mares}

The increased number of foals born every year justifies the development of research examining the factors influencing the quality of mare milk. A significant number of foals are born with inappropriate joints or show signs of Developmental Orthopaedic Disease (DOD) before weaning. Rapid growth and body development predispose to the development of various types of disorders (Thompson et al., 1988). Healthy foals are born with around $10 \%$ of their adult body weight and reach $50 \%$ of their adult weight at weaning. Therefore, the period of nursing is of paramount importance in their lives.

The feeding and nutrition of mares and the intake of nutrients from the colostrum or milk by the foal are critical factors that are known to affect the growth period and health of foals. The first nutrient of foals is the mares' colostrum. Colostrum and milk provide energy, nutrients and non- 
nutritive ingredients such as immunoglobulins, cellular elements, enzymes and hormones such as Insulin-like Growth Factor 1 (IGF-1). Protective elements of the milk play a key role in the development of the immune system, metabolism, growth of the musculoskeletal system and disease prevention. The colostral time of mares is short and components of the colostrum change within $12 \mathrm{~h}$ after calving (Becvarova and Buechner-Maxwell, 2012).

The most common components of the whey protein fraction of mares' milk are $\beta$-lactoglobulin (LGB) and $\alpha$ lactalbumin (LALBA). These proteins make up about $60 \%$ of the total whey proteins (Salimei and Fantuz, 2012). Although LGB was discovered more than 80 years ago, its function remains unclear (Foekel et al., 2009). Presumably, $\beta$-lactoglobulin plays a role in the transport of various substances or small molecules: it may facilitate the uptake of lipophilic vitamins and modify the activity of enzymes. Similar to bovine lactoglobulin, equine lactoglobulin has two isoforms called LGB1 and LGB2. However, while bovine $\beta$-lactoglobulin isoforms are the consequence of missense polymorphisms and occur within the same gene (Threadgill and Womack, 1990), horses have two distinct, paralogous genes that encode LGB1 and LGB2 (Brinkmann et al., 2016). Both genes consist of seven exons and are located on chromosome 25 (ECA25). The total lengths of LGB1 and LGB2 are 4,739 base pairs and 4,816 base pairs, respectively (GenBank NC_009168.3). Wodas et al. (2020) reported statistical correlations, such as the effect of two linked LGB1 SNPs on the total milk protein content $(P<0.01)$ and lactoglobulin substance. This study also proved that the breed had a significant effect on both gene transcript levels $(P<$ $0.01)$ and on milk LGB content $(P<0.05)$.

\section{PPARGC1A (peroxisome proliferator-activated receptor-gamma-coactivator-1-alpha gene)}

Skeletal muscles have a remarkable ability to respond to metabolic stress induced by physical activity. The metabolic energy demand generated by exercises is limited by the availability of adenosine triphosphate (ATP) in the muscles, the oxidative activity of enzymes, the mitochondrial content and the amount of available oxygen. The discovery of PPARGC1A gene encoding PGC- $1 \alpha$ protein was a major milestone in the understanding of the molecular function that led to exercise-induced phenotypic adaptations in mammalian skeletal muscle. These adaptations include the following: oxidative phosphorylation, mitochondrial biogenesis, muscle fibre type changes and angiogenesis (blood vessel formation) (Handschin et al., 2003; Arany, 2008). Exercise is an effective inducer of the PPARGC1A gene and PGC- $1 \alpha$ protein expression in human and mouse skeletal muscles (Pilegaard et al., 2003; Russell et al., 2005; Wende et al., 2005). During exercise, several signalling pathways are activated, which are considered to be key regulators of PGC- $1 \alpha$ activity.

Calcineurin (Handschin et al., 2003), p38 mitogen-activated protein kinase (MAPK) (Akimoto et al., 2005) and adenosine monophosphate- (AMP-) activated protein kinase
(AMPK) (Jager et al., 2007) signalling pathways directly affect PGC- $1 \alpha$ activity. PGC- $1 \alpha$ is an effective activator of various transcriptional coactivators such as nuclear respiratory factors 1 and 2 (NRF1 and NRF2). These proteins bind to several mitochondrial genes, then interact in the nucleus, resulting in increased mitochondrial biogenesis (Lin et al., 2005). Mitochondrial fatty acid oxidation is regulated by PCG- $1 \alpha$ with a peroxisome proliferator-activated alpha receptor. In addition, PCG- $1 \alpha$ has been shown to affect fatty acid oxidation through its interaction with the oestrogenrelated receptor alpha (ERR $\alpha$ ) of PDK4 (Wende et al., 2005; Zhang and Teng, 2007).

Previously pAMPKa (phosphoadenosine monophosphateactivated protein kinase) activity and appearance of PGC- $1 \alpha$ proteins in skeletal muscles of Thoroughbreds were observed by Eivers et al. (2009) after a single workout. A significant increase in the expression of the PPARGC1A gene encoding PGC- $1 \alpha$ has also been reported (Pilegaard et al., 2003; McGee and Hargreaves, 2004; Akimoto et al., 2005; Wright et al., 2007McGee and Hargreaves, 2004; Wright et al., 2007). PGC$1 \alpha$ plays a key role in the energy metabolism as well as the resistance to fatigue in humans and rodents.

\section{PPAR $\delta$ (peroxisome proliferator-activated receptor delta gene)}

A number of economic traits in Thoroughbreds including speed and stamina are associated with exercise. Previously complete transcriptome analysis and RNA sequencing have been used (Park et al., 2012) to identify exercise-related genes. Peroxisome proliferator-activated receptors (PPARs), which are members of the nuclear receptor superfamily, were identified in the Xenopus species (Krey et al., 1993). PPARs can be activated and interact with thyroid hormone and retinoid $\mathrm{X}$ receptors to form a heterodimeric complex which regulates transcription of target genes (Wahli et al., 1995). PPARs play a fundamental role in the differentiation, development, and metabolism (carbohydrate, lipid, protein) of cells and the regulation of tumourigenesis (Berger and Moller, 2002; Belfiore et al., 2009).

Among PPARs, PPAR $\delta$ (delta) plays an important role in muscle fat metabolism. In a study on knockout mice, PPAR $\delta$ has been shown to activate fatty acid oxidation in muscles and increase the conversion of glucose to fatty acid in the liver (Lee et al., 2006). Overexpression of PPAR $\delta$ resulted in increased oxidative metabolism and hyperplasia, which altered the fibre composition of muscles in experimental mice (Luquet et al., 2003). PPAR $\delta$, along with its metabolic role in muscle, also functions as an important regulator of satellite cell proliferation and muscle regeneration (Angione et al., 2011).

$\operatorname{PPAR} \delta$ is known as a regulator of $\beta$-oxidation, muscle fibre transformation and stamina. Hyun-Woo et al. (2015) demonstrated the occurrence of positive selection in the equine $\operatorname{PPAR} \delta$ gene using evolutionary analysis with synonymous and non-synonymous mutation ratios. The observed gene was expressed in all tissues of the examined horses and the expression level varied depending on tissues. In skeletal muscle, PPAR $\delta$ level was approximately two and 
a half times higher after $30 \mathrm{~min}$ of training. Two important domains are associated with nuclear hormone receptors, namely the $\mathrm{C} 4$ zinc finger and the ligand-binding domain, which are well conserved in the equine PPAR $\delta$.

Due to the evolutionary conservation of the equine $\operatorname{PPAR} \delta$ gene and its tissue and exercise-dependent expression, this gene may be useful in physical fitness testing of horses and also as a biomarker for equine stamina (HyunWoo et al., 2015).

\section{CONCLUSIONS}

Despite the massive potential concerning application of genomics in horses, the implementation of routine genomic examinations in the Hungarian horse racing industry is currently ignored.

A few years ago, high-impact genes with putative performance-related variants were reported in case of Thoroughbreds (Momozawa et al., 2007; Hill et al., 2010). However, the multifactorial background of breeding goal traits indicates the limitations of single-locus test approaches.

Long-term perspectives suggest that genome-wide approaches may gain practical relevance in the breeding of Thoroughbreds which enable the adoption of new genomic tools, optimised management and sustainable breeding decisions for the horse racing industry (Stock et al., 2016).

Although considerable breed differences have been observed, due to their linkage disequilibrium patterns and detailed pedigree information, trait-associated sequence variants can be more easily identified in Thoroughbreds than in other horse breeds (McCue et al., 2012).

The above-presented candidate genes, based on previous results, could have an influence on the racing ability and competitive performance of Thoroughbreds by affecting gene expression and signalling pathways.

\section{ACKNOWLEDGMENT}

The project was supported by the Hungarian Co-operative Doctoral Program (KDP 2020).

\section{REFERENCES}

Akimoto, T., Pohnert, S. C., Li, P., Zhang, M., Gumbs, C., Rosenberg, P. B., Williams, R. S. and Yan, Z. (2005): Exercise stimulates Pgc1alpha transcription in skeletal muscle through activation of the p38 MAPK pathway. J. Biol. Chem. 280, 19587-19593.

Akira, S., Uematsu, S. and Takeuchi, O. (2006): Pathogen recognition and innate immunity. Cell 124, 783-801.

Alliouachene, S., Bilanges, B., Chaussade, C., Pearce, W., Foukas, L. C., Scudamore, C. L., Moniz, L. S. and Vanhaesebroeck, B. (2016): Inactivation of class II PI3K-C2 $\alpha$ induces leptin resistance, age-dependent insulin resistance and obesity in male mice. Diabetologia 59, 1503-1512.
Andreelli, F., Laville, M., Ducluzeau, P. H., Vega, N., Vallier, P., Khalfallah, Y., Riou, J. P. and Vidal, H. (1999): Defective regulation of phosphatidylinositol-3-kinase gene expression in skeletal muscle and adipose tissue of non-insulin-dependent diabetes mellitus patients. Diabetologia 42, 358-364.

Angione, A. R., Jiang, C., Pan, D., Wang, Y. X. and Kuang, S. (2011): PPARdelta regulates satellite cell proliferation and skeletal muscle regeneration. Skelet. Muscle 1, 33.

Arany, Z. (2008): PGC-1 coactivators and skeletal muscle adaptations in health and disease. Curr. Opin. Genet. Dev. 18, 426-434.

Becvarova, I. and Buechner-Maxwell, V. (2012): Feeding the foal for immediate and long-term health. Equine Vet. J. 44, 149-156.

Belfiore, A., Genua, M. and Malaguarnera, R. (2009): PPAR-gamma agonists and their effects on IGF-I receptor signaling: Implications for cancer. PPAR Res. 2009 ID830501.

Berger, J. and Moller, D. E. (2002): The mechanisms of action of PPARs. Annu. Rev. Med. 53, 409-435.

Binns, M., Boehler, D. A. and Lambert, D. H. (2010): Identification of the myostatin locus (MSTN) as having a major effect on optimum racing distance in the Thoroughbred horse in the USA. Anim. Genet. 41, 154-158.

Bourque, G. (2009): Transposable elements in gene regulation and in the evolution of vertebrate genomes. Curr. Opin. Genet. Dev. 19, 607-612.

Bower, M. A., McGivney, B. A., Campana, M. G., Gu, J., Andersson, L. S., Barrett, E., Davis, C. R., Mikko, S., Stock, F., Voronkova, V., Bradley, D. G., Fahey, A. G., Lindgren, G., MacHugh, D. E., Sulimova, G. and Hill, E. W. (2012): The genetic origin and history of speed in the Thoroughbred racehorse. Nat. Commun. 3, 643 .

Brinkmann, J., Jagannathan, V., Drögemüller, C., Rieder, S., Leeb, T., Thaller, G. and Tetens, J. (2016): DNA-based analysis of protein variants reveals different genetic variability of the paralogous equine B-lactoglobulin genes LGB1 and LGB2. Livest. Sci. 187, 181-185.

Bruno, C., Löfberg, M., Tamburino, L., Jänkälä, H., Hadjigeorgiou, G. M., Andreu. A. L., Shanske, S., Somer, H. and Dimauro, S. (1999): Molecular characterization of McArdle's disease in two large Finnish families. J. Neurol. Sci. 165, 121-125.

Buchman, V. L., Chumakov, P. M., Ninkina, N. N., Samarina, O. P. and Georgiev, G. P. (1988): A variation in the structure of the protein-coding region of the human $\mathrm{p} 53$ gene. Gene 70, 245-252.

Buhl, R., Ersbøll, A., Eriksen, L. and Koch, J. (2005): Changes over time in echocardiographic measurements in young Standardbred racehorses undergoing training and racing and association with racing performance. J. Am. Vet. Med. Assoc. 226, 1881-1887.

Caetano, A. R., Pomp, D., Murray, J. D. and Bowling, A. T. (1999): Comparative mapping of 18 equine type I genes assigned by somatic cell hybrid analysis. Mammalian Genome 10, 271-276.

Coulam, C. B., Kay, C. and Jeyendran, R. S. (2006): Role of p53 codon 72 polymorphism in recurrent pregnancy loss. Reprod. Biomed. Online 12, 378-382.

Crackower, M. A., Oudit, G. Y., Kozieradzki, I., Sarao, R., Sun, H., Sasaki, T., Hirsch, E., Suzuki, A., Shioi, T., Irie-Sasaki, J., Sah, R., Cheng, H-Y. M., Rybin, V. O., Lembo, G., Fratta, L., Oliveirados-Santos, A. J., Benovic, J. L., Kahn, C. R., Izumo, S., Steinberg, S. F., Wymann, M. P., Backx, P. and Penninger, J. M. (2002): Regulation of myocardial contractility and cell size by distinct PI3K-PTEN signalling pathways. Cell 110, 737-749. 
Cunningham, E. P., Dooley, J. J., Splan, R. K. and Bradley, D. G. (2001): Microsatellite diversity, pedigree relatedness and the contributions of founder lineages to thoroughbred horses. Anim. Genet. 32, 360-364.

Diamond, G., Legarda, D. and Ryan, L. K. (2000): The innate immune response of the respiratory epithelium. Immunol. Rev. 173, 27-38.

Drago, A., De Ronchi, D. and Serretti, A. (2008): 5-HT1A gene variants and psychiatric disorders: a review of current literature and selection of SNPs for future studies. Int. J. Neuropsychopharmacol. 11, 701-721.

Eivers, S. S., McGivney, B. A., Fonseca, R. G., MacHugh, D. E., Menson, K., Park, S. D., Rivero, J-L. L., Taylor, C. T., Katz, L. M. and Hill, E. W. (2009): Alterations in oxidative gene expression in equine skeletal muscle following exercise and training. Physiol. Genomics 40, 83-93.

Foekel, C., Schubert, R., Kaatz, M., Schmidt, I., Bauer, A., Hipler, UC., Vogelsang, H., Rabe, K. and Jahreis, G. (2009): Dietetic effects of oral intervention with mares' milk on the Severity Scoring of Atopic Dermatitis, on faecal microbiota and on immunological parameters in patients with atopic dermatitis. Int. J. Food Sci. Nutr. 60, Suppl. 7, 41-52.

Frellstedt, L., Waldschmidt, I., Gosset, P., Desmet, C., Pirottin, D., Bureau, F., Farnir, F., Franck, T., Dupuis-Tricaud, M-C., Lekeux, P. and Art, T. (2014): Training modifies innate immune responses in blood monocytes and in pulmonary alveolar macrophages. Am. J. Respir. Cell. Mol. Biol. 51, 135-142.

Gautron, S., Daegelen, D., Mennecier, F., Dubocq, D., Kahn, A. and Dreyfus, J. C. (1987): Molecular mechanisms of McArdle's disease (muscle glycogen phosphorylase deficiency). RNA and DNA analysis. J. Clin. Invest. 79, 275-281.

Ginther, O. J., Gastal, E. L., Gastal, M. O., Bergfelt, D. R., Baerwald, A. R. and Pierson, R. A. (2004): Comparative study of the dynamics of follicular waves in mares and women. Biol. Reprod. 71, 1195-1201.

Gleeson, M., McFarlin, B. and Flynn, M. (2006): Exercise and tolllike receptors. Exerc. Immunol. Rev. 12, 34-53.

Griebel, P. J., Brownlie, R., Manuja, A., Nichani, A., Mookherjee, N., Popowych, Y., Mutwiri, G., Hecker, R. and Babiuk, L. A. (2005): Bovine toll-like receptor 9: A comparative analysis of molecular structure, function and expression. Vet. Immunol. Immunopathol. 108, 11-16.

Grobet, L., Pirottin, D., Farnir, F., Poncelet, D., Royo, L. J., Brouwers, B., Christians, E., Desmecht, D., Coignoul, F., Kahn, R. and Georges, M. (2003): Modulating skeletal muscle mass by postnatal, musclespecific inactivation of the myostatin gene. Genesis 35, 227-238.

Gross, C., Zhuang, X., Stark, K., Ramboz, S., Oosting, R., Kirby, L., Santarelli, L., Beck, S. and Hen, R. (2002): Serotonin 1A receptor acts during development to establish normal anxiety-like behaviour in the adult. Nature 416, 396-400.

Gu, J., Orr, N., Park, S. D., Katz, L. M., Sulimova, G., MacHugh, D. E. and Hill, E. W. (2009): A genome scan for positive selection in thoroughbred horses. PLoS One 4, e5767.

Hall, S. E., Upton, R. M. O., McLaughlin, E. A. and Sutherland, J. M. (2018): Phosphoinositide 3-kinase/protein kinase B (PI3K/ $\mathrm{AKT}$ ) and Janus kinase/signal transducer and activator of transcription (JAK/STAT) follicular signalling is conserved in the mare ovary. Reprod. Fertil. Dev. 30, 624.
Handschin, C., Rhee, J., Lin, J., Tarr, P. T. and Spiegelman, B. M. (2003): An autoregulatory loop controls peroxisome proliferator-activated receptor gamma coactivator 1 alpha expression in muscle. Proc. Natl. Acad. Sci. U.S.A. 100, 7111-7116.

Hayashi, K., Saga, H., Chimori, Y., Kimura, K., Yamanaka, Y. and Sobue, K. (1998): Differentiated phenotype of smooth muscle cells depends on signaling pathways through insulin-like growth factors and phosphatidylinositol 3-kinase. J. Biol. Chem. 273, 28860-28867.

Hill, E. W., Gu, J., Eivers, S. S., Fonseca, R. G., McGivney, B. A., Govindarajan, P., Orr, N., Katz, L. M. and MacHugh, D. (2010): A sequence polymorphism in MSTN predicts sprinting ability and racing stamina in Thoroughbred horses. PLoS One 5, e8645.

Hinchcliff, K. W., Geor, R. J. and Kaneps, A. J. (2008): Equine Exercise Physiology. Saunders/Elsevier, Edinburgh.

Hori, Y., Tozaki, T., Nambo, Y., Sato, F., Ishimaru, M., InoueMurayama, M. and Fujita, K. (2015): Evidence for the effect of serotonin receptor 1A gene (HTR1A) polymorphism on tractability in Thoroughbred horses. Anim. Genet. 47, 62-67.

Hosoyama, T., Kawada, S., Oshiumi, R., Yoneda, S., Soeta, C., Yamanouchi, K., Hasegawa, T., Ishida, N., Mukoyama, H., Ishii, N. and Tachi, C. (2002): Molecular cloning of equine (Thoroughbred) myostatin cDNA and detection of myostatin precursor proteins in the serum. J. Reprod. Dev. 48, 335-342.

$\mathrm{Hu}, \mathrm{W}$. (2009): The role of p53 gene family in reproduction. Cold Spring Har. Perspect. Biol. 1, a001073.

Hyun-Woo, C., Sangsu, S., Jeong-Woong, P., Jae-Young, C., NamYoung, K., Woon-Kyu, L., Lee, H-K., Song, K-D. and Cho, BW. (2015): Molecular characterization and expression analysis of the peroxisome proliferator activated receptor delta (PPAR $\delta$ ) gene before and after exercise in horse. Asian-Australas. J. Anim. Sci. 28, 697-702.

Jager, S., Handschin, C., St-Pierre, J. and Spiegelman, B. M. (2007): AMP activated protein kinase (AMPK) action in skeletal muscle via direct phosphorylation of PGC-1alpha. Proc. Natl. Acad. Sci. U.S.A. 104, 12017-12022.

John, G. B., Gallardo, T. D., Shirley, L. J. and Castrillon, D. H. (2008): Foxo3 is a PI3K-dependent molecular switch controlling the initiation of oocyte growth. Dev. Biol. 321, 197-204.

Kay, C., Jeyendran, R. S. and Coulam, C. B. (2006): P53 tumour suppressor gene polymorphism is associated with recurrent implantation failure. Reprod. Biomed. Online 13, 492-496.

Krey, G., Keller, H., Mahfoudi, A., Medin, J., Ozato, K., Dreyer, C. and Wahli, W. (1993): Xenopus peroxisome proliferator activated receptors: genomic organization, response element recognition, heterodimer formation with retinoid $\mathrm{X}$ receptor and activation by fatty acids. J. Steroid Biochem. Mol. Biol. 47, 65-73.

Kritz, N. G., Hodgson, D. R. and Rose, R. J. (2000): Prevalence and clinical importance of heart murmurs in racehorses. J. Am. Vet. Med. Assoc. 216, 1441-1445.

Larson, G. and Burger, J. A. (2013): Population genetics view of animal domestication. Trends Genet. 29, 197-205.

Lee, C. H., Olson, P., Hevener, A., Mehl, I., Chong, L. W., Olefsky, J. M., Gonzalez, F. J., Ham, J., Kang, H., Peters, J. M. and Evans, R. M. (2006): PPARdelta regulates glucose metabolism and insulin sensitivity. Proc. Natl. Acad. Sci. U.S.A. 103, 3444-3449.

Lee, S. J. (2007): Sprinting without myostatin: A genetic determinant of athletic prowess. Trends Genet. 23, 475-477. 
Lemonde, S., Turecki, G., Bakish, D., Du, L., Hrdina, P. D., Bown, C. D., Sequeira, A., Kushwaha, N., Morris, S. J., Basak, A., Ou, X-M. and Albert, P. R.: (2003): Impaired repression at a 5hydroxytryptamine 1a receptor gene polymorphism associated with major depression and suicide. J. Neurosci. 23, 8788-8799.

Leon, P. M. M., Campos, V. F., Thurow, H. S., Hartwig, F. P., Selau, L. P., Dellagostin, O. A. and Collares, T. (2012): Association between single nucleotide polymorphisms in p53 and abortion in Thoroughbred mares. Vet. J. 193, 573-575.

Librado, P., Fages, A., Gaunitz, C., Leonardi, M., Wagner, S., Khan, N., Hanghøj, K., Alquraishi, S. A., Alfarhan, A. H., Al-Rasheid, K. A., Sarkissian, C. D., Schubert, M. and Orlando, L. (2016): The evolutionary origin and genetic makeup of domestic horses. Genetics 204, 423-434.

Librado, P., Gamba, C., Gaunitz, C., Der Sarkissian, C., Pruvost, M., Albrechtsen, A., Fages, A., Khan, N., Schubert, M., Jagannathan, V., Serres-Armero, A., Kuderna, L. F. K., Povolotskaya, I. S., Seguin-Orlando, A., Lepetz, S., Neuditschko, M., Thèves, C., Alquraishi, S., Alfarhan, A. H., Al-Rasheid, K., Rieder, S., Samashev, Z., Francfort, H-P., Benecke, N., Hofreiter, M., Ludwig, A., Keyser, C., Marques-Bonet, T., Ludes, B., Crubézy, E., Leeb, T., Willerslev, L. and Orlando, L. (2017): Ancient genomic changes associated with domestication of the horse. Science 356, 442-445.

Lin, H.-Y., Huang, C.-H., Wu, W.-J., Chang, L.-C. and Lung, F.-W. (2008): TP53 codon 72 gene polymorphism paradox in associated with various carcinoma incidences, invasiveness and chemotherapy responses. Int. J. Biomed. Sci. 4, 248-254.

Lin, J., Handschin, C. and Spiegelman, B. M. (2005): Metabolic control through the PGC-1 family of transcription coactivators. Cell Metabol. 1, 361-370.

Lucki, I. (1998): The spectrum of behaviors influenced by serotonin. Biol. Psychiatry 44, 151-162.

Luquet, S., Lopez-Soriano, J., Holst, D., Fredenrich, A., Melki, J., Rassoulzadegan, M. and Grimaldi, P. A. (2003): Peroxisome proliferator-activated receptor delta controls muscle development and oxidative capability. FASEB J. 17, 2299-2301.

Manuja, A., Kumar, P., Kumar, R., Kumar, B., Singha, H., Sharma, R. K. and Yadav, S. C. (2014): CpG-ODN class C-mediated immunostimulation and its potential against Trypanosoma evansi in equines. Int. Immunopharmacol. 22, 366-370.

Martín, M. A., Rubio, J. C., García, A., Fernández, M. A., Campos, Y., Krawczak, M., Cooper, D. N. and Arenas, J. (2001): Resolution of a mispaired secondary structure intermediate could account for a novel micro-insertion/deletion (387 insA/del 8 bp) in the PYGM gene causing McArdle's disease. Clin. Genet. 59, 48-51.

McCue, P. M. (1998): Review of ovarian abnormalities in the mare. Proc. Annu. Conv. AAEP 44, 125-133.

McCue, M. E., Bannasch, D. L., Petersen, J. L., Gurr, J., Bailey, E., Binns, M. M. and Distl, O. (2012): A high-density SNP array for the domestic horse and extant perissodactyla: Utility for association mapping, genetic diversity, and phylogeny studies. PloS Genet. 8, e1002451.

McGee, S. L. and Hargreaves, M. (2004): Exercise and myocyte enhancer factor 2 regulation in human skeletal muscle. Diabetes 53, 1208-1214.

McPherron, A. C., Lawler, A. M. and Lee, S.-J. (1997): Regulation of skeletal muscle mass in mice by a new TGF- $\beta$ superfamily member. Nature 387, 83-90.
Momozawa, Y., Takeuchi, Y., Tozaki, T., Kikusui, T., Hasegawa, T., Raudsepp, T., Chowdhary, B. P., Kusunose, R. and Mori, Y. (2007): SNP detection and radiation hybrid mapping in horses of nine candidate genes for temperament. Anim. Genet. 38, 81-83.

Nadaj-Pakleza, A. A., Vincitorio, C. M., Laforêt, P., Eymard, B., Dion, E., Teijeira, S., Vietez, I., Jeanpierre, M., Navarro, C. and Stojkovic, T. (2009): Permanent muscle weakness in McArdle disease. Muscle Nerve 40, 350-357.

Nam, G-H., Ahn, K., Bae, J-H., Han, K., Lee, C-E., Park, K-D., Lee, S-H., Cho, B. W. and Kim, H. S. (2011): Genomic structure and expression analyses of the PYGM gene in the Thoroughbred horse. Zoolog. Sci. 28, 276-280.

O’Brien, R. M. and Granner, D. K. (1996): Regulation of gene expression by insulin. Physiol. Rev. 76, 1109-1161.

Ono, M., Akuzawa, H., Nambo, Y., Hirano, Y., Kimura, J., Takemoto, S., Nakamura, S., Yokota, H., Himeno, R., Higuchi, T., Ohtaki, T. and Tsumagari, S. (2015): Analysis of the equine ovarian structure during the first twelve months of life by three-dimensional internal structure microscopy. J. Vet. Med. Sci. 77, 1599-1603.

Orlando, L., Ginolhac, A., Zhang, G., Froese, D., Albrechtsen, A., Stiller, M., Schubert, M., Cappellini, E., Petersen, B., Moltke, I., Johnson, P. L. F., Fumagalli, M., Vilstrup, J. T., Raghavan, M., Korneliussen, T., Malaspinas, A-S., Vogt, J., Szklarczyk, D., Kelstrup, C. D., Vinther, J., Dolocan, A., Stenderup, J., Velazquez, A. M. V., Cahill, J., Rasmussen, M., Wang, X., Min, J., Zazula, G. D., Seguin-Orlando, A., Mortensen, C., Magnussen, K., Thompson, J. F., Weinstock, J., Gregersen, K., Røed, K. H., Eisenmann, V., Rubin, C. J., Miller, D. C., Antczak, D. F., Bertelsen, M. F., Brunak, S., Al-Rasheid, K. A. S., Ryder, O., Andersson, L., Mundy, J., Krogh, A., Gilbert, M. T. P., Kjær, K., Sicheritz-Ponten, T., Jensen, L. J., Olsen, J. V., Hofreiter, M., Nielsen, R., Shapiro, B., Wang, J. and Willerslev, E. (2013): Recalibrating Equus evolution using the genome sequence of an early Middle Pleistocene horse. Nature 499, 74-78.

Park, K. D., Park, J., Ko, J., Kim, B. C., Kim, H. S., Ahn, K., Do, KT., Choi, H., Kim, H-M., Song, S., Lee, S., Jho, S., Kong, H-S., Yang, Y. M., Jhun, B-H., Kim, C., Kim, T-H., Hwang, S., Bhak, J., Lee, H-K. and Cho, B-W. (2012): Whole transcriptome analyses of six thoroughbred horses before and after exercise using RNA-Seq. BMC Genomics 13, 473.

Pilegaard, H., Saltin, B. and Neufer, P. D. (2003): Exercise induces transient transcriptional activation of the PGC-1alpha gene in human skeletal muscle. J. Physiol. 546, 851-858.

Ramboz, S., Oosting, R., Amara, D. A., Kung, H. F., Blier, P., Mendelsohn, M., Mann, J. J., Brunner, D. and Hen, R. (1998): Serotonin receptor 1A knockout: An animal model of anxietyrelated disorder. Proc. Natl. Acad. Sci. U.S.A. 95, 14476-14481.

Ross-Ibarra, J., Morrell, P. L. and Gaut, B. S. (2007): Plant domestication, a unique opportunity to identify the genetic basis of adaptation. Proc. Natl. Acad, Sci. U.S.A. 104, Suppl. 1, 8641-8648.

Russell, A. P., Hesselink, M. K., Lo, S. K. and Schrauwen, P. (2005): Regulation of metabolic transcriptional co-activators and transcription factors with acute exercise. FASEB J. 19, 986-988.

Salimei, E. and Fantuz, F. (2012): Equid milk for human consumption. Int. Dairy J. 24, 130-142.

Schubert, M., Jónsson, H., Chang, D., Der Sarkissian, C., Ermini, L., Ginolhac, A., Albrechtsen, A., Dupanloup, I., Foucal, A., 
Petersen, B., Fumagalli, M., Raghavan, M., Seguin-Orlando, A., Korneliussen, T. S., Velazquez, A. M. V., Stenderup, J., Hoover, C. A., Rubin, C-J., Alfarhan, A. H., Alquraishi, S. A., Al-Rasheid, K. A. S., MacHugh, D. E., Kalbfleisch, T., MacLeod, J. N., Rubin, E. M., Sicheritz-Ponten, T., Andersson, L., Hofreiter, M., Marques-Bonet, T., Gilbert, T. P., Nielsen, R., Excoffier, L., Willerslev, E., Shapiro, B. and Orlando, L. (2014): Prehistoric genomes reveal the genetic foundation and cost of horse domestication. PNAS 111, E5661-E5669.

Stock, K. F., Jönsson, L., Ricard, A. and Mark, T. (2016): Genomic applications in horse breeding. Animal Frontiers 6, 45-52.

Sutherland, J. M., Keightley, R. A., Nixon, B., Roman, S.D., Robker, R. L., Russell, D. L. and McLaughlin, E. A. (2012): Suppressor of cytokine signaling 4 (SOCS4): moderator of ovarian primordial follicle activation. J. Cell. Physiol. 227, 1188-1198.

Sutherland, J. M., Keightley, R., Robker, R. L., Russell, D. L. and McLaughlin, E. A. (2010): JAK/STAT signalling in folliculogenesis. Reprod. Fertil. Dev. 22, 44.

Tan, P., Allen, J. G., Wilton, S. D., Akkari, P. A., Huxtable, C. R. and Laing, N. G. (1997): A splice-site mutation causing ovine McArdle's disease. Neuromuscul. Disord. 7, 336-342.

Thompson, K. N., Jackson, S. G. and Rooney, J. R. (1988): The effect of above average weight gains on the incidence of radiographic bone aberrations and epiphysitis in growing horses. Equine Vet. Sci. 8, 383-385.

Threadgill, D. W. and Womack, J. E. (1990): Genomic analysis of the major bovine milk protein genes. Nucleic Acids Res. 18, 6935-6942.

Todd, E. T., Ho, S. Y. W., Thomson, P. C., Ang, R. A., Velie, B. D. and Hamilton, N. A. (2018): Founder-specific inbreeding depression affects racing performance in Thoroughbred horses. Sci. Rep. 8, 6167.

Tozaki, T., Sato, F., Ishimaru, M., Kikuchi, M., Kakoi, H., Hirota, K. I. and Nagata, S-I. (2016): Sequence variants of BIEC2-808543 near LCORL are associated with body composition in Thoroughbreds under training. J. Equine Sci. 27, 107-114.

Traub-Dargatz, J. L., Salman, M. D. and Voss, J. L. (1991): Medical problems of adult horses, as ranked by equine practitioners. J. Am. Vet. Med. Assoc. 198, 1745-1747.

Vage, J., Wade, C., Biagi, T., Fatjo, J., Amat, M., Lindblad-Toh, K. and Lingaas, F. (2010): Association of dopamine- and serotonin-related genes with canine aggression. Genes Brain Behav. 9, 372-378.

Van Den Berg, L., Vos-Loohuis, M., Schilder, M. B. H., Van Oost, B. A., Hazewinkel, H. A. W., Wade, C. M., Karlsson, E. K., Lindblad-Toh, K., Liinamo, A. E. and Leegwater, P. A. J. (2008): Evaluation of the serotonergic genes HTR1A, HTR1B, HTR2A, and SLC6A4 in aggressive behavior of Golden Retriever dogs. Behav. Genet. 38, 55-66.

Vareille, M., Kieninger, E., Edwards, M. R. and Regamey, N. (2011): The airway epithelium: soldier in the fight against respiratory viruses. Clin. Microbiol. Rev. 24, 210-229.

Vörös, K. (1997): Quantitative two-dimensional echocardiography in the horse: a review. Acta Vet. Hung. 45, 127-136.
Vörös, K., Holmes, J. R. and Gibbs, C. (1991): Measurement of cardiac dimensions with two-dimensional echocardiography in the living horse. Equine Vet. J. 23, 461-465.

Wade, C. M., Giulotto, E., Sigurdsson, S., Zoli, M., Gnerre, S., Imsland, F., Lear, T. L., Adelson, D. L., Bailey, E., Bellone, R. R., Blücker, H., Distl, O., Edgar, R. C., Garber, M., Leeb, T., Mauceli, E., MacLeod, J. N., Penedo, M. C. T., Raison, J. M., Sharpe, T., Vogel, J., Andersson, L., Antczak, D. F., Biagi T., Binns, M. M., Chowdhary, B. P., Coleman, S. J., Della Valle, G., Fryc, S., Guérin, G., Hasegawa, T., Hill, E. W., Jurka, J., Kiialainen, A., Lindgren, G., Liu, J., Magnani, E., Mickelson, J. R., Murray, J., Nergadze, S. G., Onofrio, S., Pedroni, S., Piras, M. F., Raudsepp, T., Rocchi, M., Røed, K. H., Ryder, O. A., Searle, S., Skow, L., Swinburne, J. E., Syvänen, A. C., Tozaki, T. Valberg, S. J., Vaudin, M., White, J. R., Zody, M. C., Lander, E. S. and Lindblad-Toh, K. (2009): Genome sequence, comparative analysis, and population genetics of the domestic horse. Science 326, 865-867.

Wahli, W., Braissant, O. and Desvergne, B. (1995): Peroxisome proliferator activated receptors: Transcriptional regulators of adipogenesis, lipid metabolism and more. Chem. Biol. 2, 261-266.

Wallner, B., Vogl, C., Shukla, P., Burgstaller, J. P., Druml, T. and Brem, G. (2013): Identification of genetic variation on the horse $\mathrm{Y}$ chromosome and the tracing of male founder lineages in modern breeds. PLoS One 8, e60015.

Wende, A. R., Huss, J. M., Schaeffer, P. J., Giguere, V. and Kelly, D. P. (2005): PGC-1alpha coactivates PDK4 gene expression via the orphan nuclear receptor ERRalpha: a mechanism for transcriptional control of muscle glucose metabolism. Mol. Cell. Biol. 25, 10684-10694.

Williamson, S. A. and Beilharz, R. G. (1996): Heritabilities of racing performance in Thoroughbreds: a study of Australian data. J. Anim. Breed. Genet. 113, 505-524.

Williamson, S. A. and Beilharz, R. G. (1998): The inheritance of speed, stamina and other racing performance characters in the Australian Thoroughbred. J. Anim. Breed. Genet. 115, 1-16.

Wilsher, S., Allen, W. R. and Wood, J. L. (2006): Factors associated with failure of Thoroughbred horses to train and race. Equine Vet. J. 38, 113-118.

Wodas, L., Mackowski, M., Borowska, A., Puppel, K., Kuczynska, B. and Cieslak, J. (2020): Genes encoding equine $\beta$-lactoglobulin (LGB1 and LGB2): Polymorphism, expression, and impact on milk composition. PLoS One 15, e0232066.

Wright, D. C., Han, D. H., Garcia-Roves, P. M., Geiger, P. C., Jones, T. E. and Holloszy, J. O. (2007): Exercise-induced mitochondrial biogenesis begins before the increase in muscle PGC1alpha expression. J. Biol. Chem. 282, 194-199.

Zhang, Z. and Teng, C. T. (2007): Interplay between EstrogenRelated Receptor alpha $(\operatorname{ERR} \alpha)$ and gamma $(\operatorname{ERR} \gamma)$ on the regulation of ERR $\alpha$ gene expression. Mol. Cell. Endocrinol. 264, 128-141.

Zucca, E., Ferrucci, F., Croci, C., Fabio, V. D., Zaninelli, M. and Ferro, E. (2008): Echocardiographic measurements of cardiac dimensions in normal Standardbred racehorses. J. Vet. Cardiol. 10, 45-51.

Open Access. This is an open-access article distributed under the terms of the Creative Commons Attribution 4.0 International License (https://creativecommons.org/ licenses/by/4.0/), which permits unrestricted use, distribution, and reproduction in any medium, provided the original author and source are credited, a link to the CC License is provided, and changes - if any - are indicated. (SID_1) 